\title{
EFFECTIVENESS OF MULTIDISCIPLINARY TEAM AS A NEW MODEL OF AFTER STROKE PATIENTS' REHABILITATION
}

Ivanova GE ${ }^{1,2,9}$, Melnikova EV ${ }^{1,5,8}$, Shmonin AA ${ }^{1,5,8}$, Verbitskaya EV ${ }^{5}$, Belkin AA $A^{1,3}$, Bodrova RA ${ }^{1,4,7}$, Lebedev PV ${ }^{1}$, Maltseva MN $N^{1,5}$, Prokopenko SV ${ }^{1,6}$, Prosvirnina MS ${ }^{1,8}$, Sarana AM'1 , Stakhovskaya LV'1,2, Suvorov AYu' ${ }^{1,2,9} \bowtie$, Khasanova DR ${ }^{1,4,7}$, Shamalov $\mathrm{NA}^{1,2,9}$

${ }_{1}^{1}$ All-Russian Union Rehabilitators, Moscow, Russia

2 Pirogov Russian National Research Medical University, Moscow, Russia

${ }^{3}$ Ural State Medical University, Ekaterinburg, Russia

${ }^{4}$ Kazan State Medical Academy, Kazan, Russia

${ }^{5}$ Pavlov First Saint Petersburg State Medical University, Saint Petersburg, Russia

${ }^{6}$ Krasnoyarsk State Medical University, Krasnoyarsk, Russia

7 Kazan State Medical University, Kazan, Russia

${ }^{8}$ City Hospital № 26, Saint Petersburg, Russia

${ }_{9}^{9}$ Federal Centre of Cerebrovascular Pathology and Stroke, Moscow, Russia

Modern papers on treatment and rehabilitation of stroke patients describe the advantages and effectiveness of certain medical rehabilitation types, but these data are not enough to evaluate the efficiency of the whole rehabilitation system. The study was aimed to investigate the potential of the patient-centered problem-oriented multidisciplinary three-stage system for medical rehabilitation of stroke patients. The study included 1021 patientsover 18 affected with ischemic or hemorrhagic stroke in the acute phase. All patients had a disability of admission at the time (but no persisting disability in their history). Two models of rehabilitation measures were compared in two consecutive phases of the study. The linear model of rehabilitation assistance was mainly implemented in phase 1, and the multidisciplinary model was implemented in phase 2. The patients' condition was evaluated using the Modified Rankin Scale ( $m R S)$ at the end of rehabilitation. Comparison of the $1^{\text {st }}$ and $2^{\text {nd }}$ phase results demonstrated that the number of patients with $\mathrm{mRS}$ score $0-1$ in the $2^{\text {nd }}$ phase was lower by $18 \%$. The proportion of patients with positive dynamics was significantly higher in the $2^{\text {nd }}$ phase than in the $1^{\text {st }}$ phase, (16 and $30 \%$ respectively). In the $2^{\text {nd }}$ phase there were significantly more patients who demonstrated improvement by $1-4$ (mRS score). Thus, the use of a multidisciplinary model provides a significant benefit compared with a linear rehabilitation model.

Keywords: medical rehabilitation, physical and rehabilitation medicine, multidisciplinary team, development of a medical rehabilitation system, pilot project, acute stroke, neurorehabilitation

Funding: Territorial Federal Compulsory Medical Insurance Fund, Ministry of Health of the Russian Federation and the Ministry of Education and Science of the Russian Federation universities budget funds, All-Russian Union Rehabilitators funds.

Acknowledgements: Yulia Buryak, neurologist of Pavlov First Saint Petersburg State Medical University. Victoria Kasatkina, neurologist of City Alexandovskaya Hospital. Ekaterina Lobachyova, $6^{\text {th }}$ year student of Pavlov First Saint Petersburg State Medical University.

Compliance with ethical standards: the study was approved by the Ethics Committee of Pavlov First Saint Petersburg State Medical University (No Ref. protocol dated April 11, 2018). The informed consent was submitted by all study participants.

$\bowtie$ Correspondence should be addressed: Andrey Yu. Suvorov

Ostrovityanova, 1-10, Moscow, 117342; dr_suvorov@mail.ru

Received: 26.11.2019 Accepted: 13.12.2019 Published online: 26.12.2019

DOI: $10.24075 /$ brsmu.2019.089

\section{ОЦЕНКА ЭФФЕКТИВНОСТИ РАБОТЫ МУЛЬТИДИСЦИПЛИНАРНОЙ БРИГАДЫ КАК НОВОЙ МОДЕЛИ ОКАЗАНИЯ РЕАБИЛИТАЦИОННОЙ ПОМОЩИ ПАЦИЕНТАМ С ЦЕРЕБРАЛЬНЫМ ИНСУЛЬТОМ}

Г. Е. Иванова ${ }^{1,2,9}$, Е. В. Мельникова ${ }^{1,5,8}$, А. А. Шмонин ${ }^{1,5,8}$, Е. В. Вербицкая ${ }^{5}$, А. А. Белкин ${ }^{1,3}$, Р. А. Бодрова ${ }^{1,4,7}$, П. В. Лебедев ${ }^{1}$, М. Н. Мальцева С. В. Прокопенко ${ }^{1,6}$, М. С. Просвирнина ${ }^{1,8}$, А. М. Сарана, Л. В. Стаховская, ${ }^{1,2}$, А. Ю. Суворов

'Общероссийская общественная организация содействия развитию медицинской реабилитологии “Союз реабилитологов России", Москва, Россия

2 Российский национальный исследовательский медицинский университет имени Н. И. Пирогова, Москва, Россия

${ }^{3}$ Уральский государственный медицинский университет, Екатеринбург, Россия

${ }^{4}$ Казанская государственная медицинская академия, Казань, Россия

5 Первый Санкт-Петербургский государственный медицинский университет имени И. П. Павлова, Санкт-Петербург, Россия

${ }^{6}$ Красноярский государственный медицинский университет имени В. Ф. Войно-Ясенецкого, Красноярск, Россия

${ }^{7}$ Казанский государственный медицинский университет, Казань, Россия

8 Городская больница № 26, Санкт-Петербург, Россия

9 Федеральный центр цереброваскулярной патологии и инсульта, Москва, Россия

В современных работах по лечению и реабилитации пациентов с инсультом описывают преимущества и эффективность отдельных видов медицинской реабилитации, но этих данных недостаточно для оценки эффективности реабилитационной системы в целом. Целью нашего исследования было изучить эффективность пациент-центрированной проблемно-ориентированной мультидисциплинарной трехэтапной системы медицинской реабилитации пациентов с инсультом. В исследовании принял участие 1021 пациент старше 18 лет с ОНМК по ишемическому или геморрагическому типу в острейшем периоде. Все пациенты имели ограничение жизнедеятельности на момент поступления (без стойкой инвалидизации в анамнезе). Проводили сравнение двух моделей реабилитационных мероприятий, которые осуществляли в две последовательные фазы. В фазе 1 реализовывали преимущественно модель линейной формы оказания реабилитационной помощи, а в фазе 2 - мультидисциплинарную модель. Состояние пациентов оценивали по модифицированной шкале Рэнкина (mRS) в конце курса реабилитации. Сравнение результатов, полученных в первую и вторую фазы исследования, показало, что количество пациентов с оценкой по шкале mRS 0-1 балл в фазе 2 было на 18\% меньше. Доля пациентов, имевших положительную динамику, также была значимо выше в фазе 2, чем в фазе 1 (16 и 30\% соответственно). Пациентов, продемонстрировавших улучшение на 1-4 балла, в фазе 2 было значимо больше. Таким образом, применение мультидисциплинарной модели по сравнению с линейной моделью реабилитации обеспечивает значимое улучшение.

Ключевые слова: медицинская реабилитация, физическая и реабилитационная медицина, мультидисциплинарная бригада, развитие системы медицинской реабилитации, пилотный проект, ОНМК, нейрореабилитация

Финансирование: средства ТФОМС, бюджетные средства вузов МЗ РФ и МОН РФ, средства Общероссийской общественной организации содействия развитию медицинской реабилитологии «Союз реабилитологов России».

Благодарности: Буряк Юлии, врачу-неврологу и Лобачевой Екатерине, студентке 6 курса ПСПбГМУ имени И. П. Павлова; Касаткиной Виктории, врачу-неврологу из СПб ГБУЗ «Городская Александровская больница».

Соблюдение этических стандартов: исследование одобрено этическим комитетом ПСПбГМУ имени И. П. Павлова (заседание от 11 апреля 2018 г.). Добровольное информированное согласие на участие в исследовании подписано всеми участниками.

$\bowtie$ Для корреспонденции: Андрей Юрьевич Суворов

ул. Островитянова, д. 1, стр. 10, г. Москва, 117342; dr_suvorov@mail.ru

Статья получена: 26.11.2019 Статья принята к печати: 13.12.2019 Опубликована онлайн: 26.12.2019

DOI: $10.24075 /$ vrgmu.2019.089 
Various terms are used in the literature to describe the work of a multidisciplinary team (MDT) in medical rehabilitation [1-3]. It is written in the White Book on Physical and Rehabilitation Medicine (PRM) in Europe, that the rehabilitation team should work using a multi-professional, interdisciplinary, team-based approach [4-6]. In Russia, this principle is called multidisciplinary [1].

The study was aimed to investigate the efficiency of a patient-centered, problem-oriented multidisciplinary threestage system of medical rehabilitation of patients with stroke compared with the linear rehabilitatopn model in the framework of a multi-center study.

\section{METHODS}

The study protocol was published earlier [7-9].

The study design was comparative, consistent and included two phases. The study involved 22 medical organizations of the first, second and third stages of medical rehabilitation from 8 regions of the Russian Federation: St. Petersburg, the Tver Region, the Sverdlovsk Region, the Republic of Tatarstan, the Krasnoyarsk Region, Chuvash Republic, Perm Krai. The staffing and equipment of all centers complied with the order of medical rehabilitation (order of the Ministry of Health of the Russian Federation № 1705H dated 29.12.2012) [10] and with the order of medical care for patients with stroke (order of the Ministry of Health of the Russian Federation № 928H dated 15.11.2012) [11].

Comparative study if the biomedical and biopsychosocial medical rehabilitation models, implemented in phases 1 and 2, was published earlier [8, 9]. Phase 1 was the work of a rehabilitation MDT that implemented a biomedical rehabilitation model (all specialists worked separately, without discussing the problems of patients at the MDT meetings). Neurologists directed the patients to physical therapists, speech-language pathologists, physiatrists and psychologists. Functional impairments were described in accordance with accepted forms and formalized records in the patient history. Rehabilitation diagnosis was not made, rehabilitation goal was not formulated. To assess the condition of the patient, only the International Classification Of Diseases (ICD-10) was used. The International Classification of Functioning, Disability and Health (ICF) was not used. During the 1st phase all MDT specialists were trained at 5 medical universities of the Ministry

Table 1. List of scales used in the phase 2 of Health of the Russian Federation and one university of the Ministry of Education and Science of the Russian Federation (Pirogov Russian National Research Medical University, Pavlov First Saint Petersburg State Medical University, Ivanovo State Medical Academy, Krasnoyarsk State Medical University and Lobachevsky State University of Nizhny Novgorod). All centers used the same training program.

The training program included blocks on general issues of medical rehabilitation, as well as blocks on particular issues of cardiological and neurological rehabilitation, rehabilitation traumatology, on psychological correction, occupational therapy, physical therapy, speech-language therapy. Specialists were trained to organize and conduct a multidisciplinary rehabilitation process, to use ICF, to draw up the rehabilitation diagnosis and plan. The program involved training of specialists in basic rehabilitation interventions in accordance with Russian clinical recommendations [12] nd recommendations of the European Society of Physical and Rehabilitation Medicine (ESPRM) [4-6, 13-21].

The main group of specialists, who developed the training programs for the project participants and organized the educational process, was previously trained by the ESPRM specialists [7] according to the training program on physical and rehabilitation medicine. The training program was modular. The training programs available in Russia were supplemented by modules on medical and social rehabilitation as well as the other modules. Training and re-training were a key element of the study.

Phase 2 implementing the new rehabilitation model began after the completion of MDT specialists training. To assess the conformity of the educational bases of universities with the implemented training models, a clinical bases' audit was conducted by Russian and European specialists. It was concluded that all clinical training facilities for MDT specialists were complied with the rehabilitation organization order, the research protocol and European standards of rehabilitation [22].

In phase 2, medical organizations worked in accordance with principles, implementing a patient-centered, problemoriented multidisciplinary (bio-psychosocial) approach [8]. The occupational therapist or a specialist who fulfilled the functional duties of an occupational therapist after special training (specialist with basic higher pedagogical, psychological or medical education) was included in the MDT. The program for

\begin{tabular}{|c|c|}
\hline Specialist & Scale \\
\hline \multirow{4}{*}{$\begin{array}{l}\text { Rehabilitation } \\
\text { physician } \\
\text { (neurologist) }\end{array}$} & National Institutes of Health Stroke Scale (NIHSS) \\
\hline & Modified Rankin Scale (mRS) \\
\hline & Pain Visual Analogue Scale (VAS) \\
\hline & Modified Ashworth Scale (MAS) \\
\hline \multirow{2}{*}{ Psychologist } & Montreal Cognitive Assessment (MoCA) \\
\hline & Hospital Anxiety and Depression Scale (HADS) \\
\hline \multirow{2}{*}{$\begin{array}{l}\text { Speech-language } \\
\text { pathologist }\end{array}$} & Scale designed by L.I. Wasserman for estimating the degree of speech disorders in patients with local brain injuries \\
\hline & Mann Assessment of Swallow Ability (MASA) \\
\hline \multirow{2}{*}{ Emergency } & National Institutes of Health Stroke Scale (NIHSS) \\
\hline & Glasgow Coma Scale \\
\hline \multirow{5}{*}{ Physical therapist } & Medical Research Council scale (MRC) \\
\hline & Berg Balance Scale (BBS) \\
\hline & Functional Independence Measure (FIM) \\
\hline & Frenchay Arm Test \\
\hline & Quality of life assessment using EuroQ-5D questionnaire \\
\hline
\end{tabular}


re-training of exercise therapy methodologists also included modules on physical therapy.

MDT worked in accordance with the ESPRM standards. All specialists met and discussed the patient's problems at the MDT meeting, set the goal of rehabilitation and drew up a rehabilitation plan. Rehabilitation diagnosis was used for coordination. Clinical psychologists and psychotherapists were actively involved to provide a patient-centered approach.

To evaluate the role of the MDT specialists, rehabilitation assessment scales were used [23]. Scales and questionnaires were distributed in accordance with the competencies of specialists to describe the main necessary for rehabilitation patient functioning indicators (Table 1). If the changes had been revealed that could be evaluated using certain scale, then such a scale was used in case of the feasibility of the assessment (for example, it is impossible to evaluate cognitive function or anxiety in a patient with a decreased consciousness). However, some scales were used regardless of the severity of the patient's condition (mRS, Rivermead Mobility Index, NIHSS and Glasgow Coma Scale). Assessment was carried out at the beginning and at the end of hospitalization at all three study stages. Specialists were allowed to use other scales and questionnaires, which were not analyzed separately.

When transferring a patient from the intensive care unit or vascular unit to the medical rehabilitation unit, only the Glasgow Coma Scale was excluded from the list of scales.

After the rehabilitation completion (1.5 years), a delayed assessment of the patient's condition based on a telephone interview with the patient or his close relatives was carried out using a modified set of tests and scales. For telephone interviewing, a group of specialists trained to perform telephone surveys was created. The training included psychologist's lectures on the psychological features of performing surveys, lectures on conflict management as well as training on mRS implementation in telephone surveys for rehabilitation physicians. After training all specialists passed the exam. The following indices were chosen for telephone assessment: mRS, Rivermead Mobility Index, adverse events and EQ-5D. During the interview, specialists had access to the patients' database, so they could use information about the patient's condition at various stages of rehabilitation to increase the interview effectiveness. The interviewers did not know to what phase of the study the patients they interacted with belonged. Patients also did not know what phase of the study they were included in. Thus, the study could be considered double blind.

Two mRS score values were selected as intermediate points of the study: the value obtained at the 1st stage of rehabilitation, and the value obtained 1.5 years (18 months) after the rehabilitation. The mRS was chosen as a universal indicator of the patient's health, disability and the patient's independence, since the scale allows one to describe any degree of disability regardless of the cause (not only related to stroke).

The study included patients with acute ischemic or hemorrhagic stroke who had a disability at the time (minimum mRS score 2) and who had not have a disability prior to stroke (score 2 or more). That is, patients without previous persistent disabilities who were independent before stroke according to information obtained from patient or his relatives were included into the study.

Inclusion criteria: ischemic or hemorrhagic stroke acute period (within 21 days from the onset), provided that surgery is not required; age over 18. Exclusion criteria: mRS score over 1 before stroke; conducting or planning of any surgery (except thrombectomy); isolated subarachnoid hemorrhage; transient ischemic attack; impaired consciousness upon admission (coma score 2 or more).

The protocol of stroke patients' survey during medical rehabilitation at all stages in phase 1 and phase 2 was published earlier [8]. After the 1st stage rehabilitation completion, the patients were directed to the $2^{\text {nd }}$ and $3^{\text {rd }}$ stage, depending on the level of vital activity restoration and the need of further rehabilitation. Thus, the patients with mRS score 4-5 were directed to the $2^{\text {nd }}$ stage of rehabilitation, and the patients with $\mathrm{mRS}$ score $2-3$ were directed to the $3^{\text {rd }}$ stage. All patients directed to the $2^{\text {nd }}$ and $3^{\text {rd }}$ stages of rehabilitation had good prospects for recovery and a prognosis of full or partial functioning restoration, or a prognosis of adaptation and compensation. Patients with a prognosis of nursing and palliative care were transferred to appropriate facilities or discharged. Patients with mRS score 0-1 were also discharged, since they had no disability and did not need rehabilitation. The sampling was continuous.

Thus, patients received a three-stage medical rehabilitation in accordance with the multidisciplinary problem-oriented and patient-centered model in phase 2 or in accordance with the biomedical model in phase 1 , which made it possible to compare the two systems of rehabilitation organization. The protocol of patients' examination used in phases 1 and 2 was the same. It was based on the current rules and regulations of the Russian Federation [10-11]) as well as clinical scales that had shown validity in Russian and foreign studies on the stroke patients rehabilitation.

ICF-reader application (developed by Shmonin AA, Maltseva MN, Melnikova EV; Saint-Petersburg, Russia) was used as an electronic registration card patients' data collection. The application was installed in all centers participating in the study; it worked in accordance with the network principle. Any registered employee could enter the application, see the patient's data and perform the assessment. The application also promoted multidisciplinary approach because of better information sharing. Due to the ICF-reader software, the research organizers could conduct an electronic audit [9, 23].

Statistical analysis was performed using the SAS software (SAS Institute Inc.; USA). The Shapiro-Wilk test was used for assessment the distribution normality. Analysis of variance (ANOVA) was used to compare the main quantitative indicators in a normal distribution. Mixed-design analysis of variance (MixedANOVA) was implemented for repeated measurements in a normal distribution. Pairwise analysis of the groups was carried out only if there were significant differences according to the Breslow-Day test. For pairwise comparisons, the Tukey-Cramer test was used. McNemar's test was applied to contingency tables with a dichotomous trait. For a distribution other than normal, the Mann-Whitney $U$ test was used for unrelated samples, and the Wilcoxon test was used for related samples. To analyze the qualitative data, the Fisher exact test and the Pearson $\chi^{2}$ test were used, depending on the number of indicators. The differences were considered significant when $p<0.05$.

The study was registered as a clinical trial in the international ClinicalTrials.gov registry with the following name: The Pilot Project Development Of Medical Rehabilitation System in Russian Federation (DOME) (NCT02793934).

\section{RESULTS}

There were 1021 patients registered in the electronic system. Prior to the study, the groups of patients were comparable in severity and major epidemiological parameters (Table 2). In 
phase 2, there was a greater number of patients with a specified stroke pathogenetic variant. Disability before stroke, as well as the the proportion of patients who received reperfusion therapy during the stroke acute period in phases 1 and 2 were comparable.

At the beginning of the study, all patients had similar indices values (Table 3)
The main endpoint of the study was the mRS score at the end of rehabilitation (Fig. 1). In the phase 2, an 18\% increase in the proportion of patients without disabilities was observed (mRS 0-1) compared with phase $1(p<0.0001)$. The mRS score in the $1^{\text {st }}$ group in the end of rehabilitation was $3(2 ; 4)$, and in the $2^{\text {nd }}$ group it was $2(1 ; 3)$ (Mann-Whitney $U$ test, $p<0.01)$

Table 2. Comparison of two groups of patients with stroke before the start of the study

\begin{tabular}{|c|c|c|c|}
\hline Indicator & Phase 1 & Phase 2 & Significance \\
\hline Nimber of patients & 498 & 523 & - \\
\hline $\operatorname{Sex}(F: M)$ & $1: 1.5$ & $1: 1.2$ & 0.06 \\
\hline Age & $68 \pm 12$ & $68 \pm 14$ & 0.32 \\
\hline Smoke & $14 \%$ & $15 \%$ & 0.26 \\
\hline Ischemic stroke & $91.2 \%$ & $92.7 \%$ & \multirow{2}{*}{0.21} \\
\hline Hemorrhagic stroke & $8.8 \%$ & $7.3 \%$ & \\
\hline Alcohol addiction & $4.5 \%$ & $3.2 \%$ & 0.16 \\
\hline Ischemic stroke history & $20 \%$ & $18 \%$ & 0.23 \\
\hline Hemorrhagic stroke history & $1 \%$ & $1 \%$ & 0.23 \\
\hline \multicolumn{4}{|c|}{ Disability history } \\
\hline mRS score before stroke 0 & $81.8 \%$ & $84.0 \%$ & \multirow{3}{*}{0.33} \\
\hline mRS score before stroke 1 & $18.0 \%$ & $16.0 \%$ & \\
\hline mRS score before stroke 2 & $0.2 \%$ & $0.0 \%$ & \\
\hline \multicolumn{4}{|c|}{ Reperfusion therapy } \\
\hline Intravenous fibrinolytic therapy & $3.5 \%$ & $1.5 \%$ & \multirow{2}{*}{0.14} \\
\hline Thrombectomy & $0.6 \%$ & $0.6 \%$ & \\
\hline \multicolumn{4}{|c|}{ Ischemik stroke pathogenesis variant } \\
\hline NYD & $11.7 \%$ & $8.0 \%$ & \multirow{6}{*}{$<0.05$} \\
\hline Atherothrombosis & $56.9 \%$ & $51.4 \%$ & \\
\hline Cardioembolic stroke & $13.3 \%$ & $19.2 \%$ & \\
\hline Lacunar stroke & $7.8 \%$ & $13.2 \%$ & \\
\hline Rare causes of stroke & $0.2 \%$ & $0.2 \%$ & \\
\hline Other & $1.2 \%$ & $0.7 \%$ & \\
\hline
\end{tabular}

Note: phase 1 - biomedical rehabilitation model; phase 2 - multidisciplinary patient-centered problem-oriented rehabilitation model

Table 3. Comparison of two groups of patients with stroke before the start of the study

\begin{tabular}{|c|c|c|c|c|c|c|}
\hline \multicolumn{4}{|c|}{ Scales } & Phase 1 & Phase 2 & Significance, Tukey-Kramer test \\
\hline \multicolumn{4}{|l|}{ NIHSS } & $6(4 ; 10)$ & $5(3 ; 9)$ & $>0.05$ \\
\hline \multicolumn{4}{|l|}{$\mathrm{MoCa}$} & $17.5(8 ; 21)$ & $18(9 ; 23)$ & 0.3287 \\
\hline \multicolumn{4}{|c|}{ Frenchay arm test } & $2(0 ; 4)$ & $3(0 ; 5)$ & 0.0765 \\
\hline \multicolumn{4}{|l|}{ FIM } & $81(56 ; 97)$ & $76(52 ; 95)$ & 0.8394 \\
\hline \multicolumn{4}{|l|}{ BBS } & $25(5 ; 38)$ & $16(0 ; 37)$ & 0.1582 \\
\hline \multirow{8}{*}{ MRC } & \multirow{4}{*}{ Hand } & \multirow{2}{*}{ Right } & Proximal & $3(0 ; 4)$ & $3(0 ; 4)$ & 0.5086 \\
\hline & & & Distal & $3(0 ; 4)$ & $3(0 ; 4)$ & 0.3538 \\
\hline & & \multirow{2}{*}{ Left } & Proximal & $3(0 ; 4)$ & $3(0 ; 4)$ & 0.0038 \\
\hline & & & Distal & $3(0 ; 4)$ & $3(0 ; 4)$ & 0.0022 \\
\hline & \multirow{4}{*}{ Leg } & \multirow{2}{*}{ Right } & Proximal & $3(0 ; 4)$ & $3(0 ; 4)$ & 0.5207 \\
\hline & & & Distal & $3(0 ; 4)$ & $3(0 ; 4)$ & 0.3081 \\
\hline & & \multirow{2}{*}{ Left } & Proximal & $3(0 ; 4)$ & $3(0 ; 4]$ & 0.0056 \\
\hline & & & Distal & $3(0 ; 4)$ & $3(0 ; 4)$ & 0.0016 \\
\hline \multicolumn{4}{|l|}{ MASA } & $179(169 ; 180)$ & $180(177 ; 180)$ & 0.5601 \\
\hline \multicolumn{4}{|c|}{ L. I. Wasserman psychodiagnostic scale } & $6(0 ; 25)$ & $0(0 ; 24)$ & 0.6027 \\
\hline \multicolumn{4}{|c|}{ EuroQ-5D } & $10(8 ; 13)$ & $11(10 ; 15)$ & 0.3648 \\
\hline \multirow{2}{*}{ HADS } & \multicolumn{3}{|c|}{ Depression } & $6(3 ; 12)$ & $8(4 ; 11)$ & 0.427 \\
\hline & \multicolumn{3}{|l|}{ Anxiety } & $7(3 ; 11)$ & $6(4 ; 10)$ & 0.9971 \\
\hline
\end{tabular}


In phase 2, the best improvement was demonstrated by patients with score 4,3 , and 2 at the moment of admission $(p=0.0009,0.0019$ and 0.001 respectively). Patients with mRS score 5 and 1 did not have any advantage in the 1 st stage during rehabilitation in phase 2 compared with phase 1 . Phase 2 rehabilitation was more effective in patients with moderate severity and disability. In severe patients and patients with no disability (mRS score 1 ), the efficiency remained the same as when using the biomedical model.

Assessment scales were the secondary endpoints роли (Table 4). By the time of the $1^{\text {st }}$ stage rehabilitation completion, the severity in accordance with the NIHSS scale in groups 1 and 2 was comparable $(p>0.05)$. The FIM score, reflecting changes in self-care, mobility, communication and social activity, showed that the 2nd group patients recovered better.

The Frenchay test (Table 4) in phase 2 revealed an improvement in the patients's condition. The number of patients with score 5 (complete restoration of hand function) was $20 \%$ more in phase 2 than in phase 1. In addition, there were less patients with the score below $0,1,2$, and 3 points in phase 2 (patients could not complete the test or made many mistakes) than in phase 1. Analysis using the Pearson $\chi^{2}$ test revealed no significant differences $(p=0.0604)$.

Assessment using the Berg Balance Scale (Table 4) revealed a significant improvement by the end of rehabilitation in patients of the 1st $(p<0.0001)$, and 2 nd groups $(p<0.0001)$. The improvement was more pronounced in the $2^{\text {nd }}$ group, however, the Tukey-Cramer test demonstrated that the differences were not significant $(p=0.0859)$. The analysis (excluding patients with normal score at the start of the experiment) showed an increase in the proportion of patients with a low risk of falling (score 41-56) by the time the hospital stay was completed in phase 2 (59\%) compared with phase 1 (47.3\%). There was a decrease in the proportion of patients with an average risk of falling (21-40 points) from 39 to $19 \%$ in phase 2 (Pearson $\chi^{2}$ test; $p=0.0077$ ).

Assessment using MASA and L.I. Wasserman demonstrated the ceiling effect. By the time of the 1st stage rehabilitation completion, it was found that patients of both groups achieved an almost complete functional restoration of swallowing (200, maximum MASA score) by median and interquartile range; therefore, there were no significant differences between the groups. By the end of the 1st stage rehabilitation, the patients of both groups achieved almost complete restoration of speech, therefore, there were no significant differences between the groups, although the median values were higher in group 2 .

Assessment of cognitive functions was carried out using MoCa. In phase 2, better cognitive functions' recovery was observed than in phase $1(p<0.0001)$. The improvement was significant both in group $1(p<0.0001)$ and in group 2 $(p<0.0001)$.

Assessment of the anxiety level using the HADS scale did not reveal any significant differences between groups 1 and 2 $(p=0.5422)$. Higher level of depression was detected in phase 2 $(p=0.0318)$. Removing of patients with a normal HADS score from a sample at the beginning of the study showed that the increase in the HADS score was due to a significant increase in the proportion of patients subclinical depression (phase 1 , $18 \%$; phase 2, 44\%; $p=0.0129$ ). The number of patients with clinical depression (HADS) in the phases 1 and 2 was the same (28.3 and $28.8 \%$ respectively).

The use of the EuroQ-5D revealed a comparable quality of life in both groups, there were no significant differences $(p=0.0887)$. The best indicators were observed in the $2^{\text {nd }}$ group. During hospitalization at the $1^{\text {st }}$ stage, both in group 1 $(p=0.0896)$ and in group $2(p=0.567)$ he quality of life did not improve, which indicated lack of said indicator sensitivity at the 1st stage of the study.

A pairwise comparison (Mann-Whitney $U$ test) showed that hospitalization was shorter in phase 2 (14 (12; 19) patient days) compared with phase 1 (16 $(14 ; 20)$ patient days; $p<0.001)$. Recalculation of the hospitalization duration in absolute terms demonstrated that in phase 2 there was a reduction (saving) in the length of hospitalization by 38\% (patient days) compared with phase 1. In phase 2, MDT specialists were advised to regulate the hospitalization duration on their own, without any limitations. Due to the introduction of a patient-centered problem-oriented multidisciplinary rehabilitation, some patients became able to remain at the $1^{\text {st }}$ stage longer, because there was a need for a longer rehabilitation. Some patients became

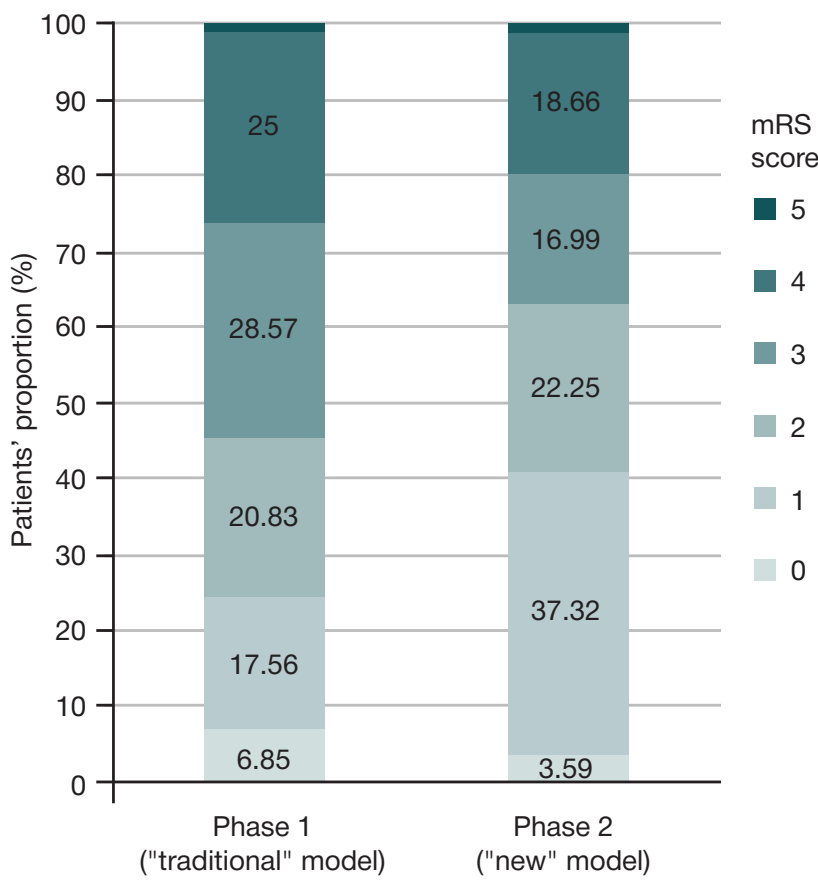

Fig. 1. Results of stroke patients rehabilitation at the end of the $1^{\text {st }}$ stage (Pearson $\chi^{2}$ test; $p<0.0001$ ) 
able to be discharged earlier if the goals of the rehabilitation program were achieved at the 1st stage. The principle of "unlimited" hospitalization periods allowed us to reduce the duration of hospitalization. Reducing the hospitalization duration at the 1st stage (taking into account the cost of care for patients with stroke in various regions from 75,000 to 180,000 rubles) should be regarded as $\mathrm{ROI}$.

To evaluate the stroke patients' condition 1.5 years after rehabilitation using a biopsychosocial patient-centered and problem-oriented model, the analysis included information on the 237 people status received from patients or their relatives. The main reason for the patient's inaccessibility for a call was the lack of a phone number (the patient did not leave a phone number, specialists did not add it to the database) or the number change. Twenty nine people refused to talk and did not explain the reason (12\%). The time between the onset and the telephone interview was comparable in both groups (Table 5), $21(19 ; 23)$ months in the $1^{\text {st }}$ group, $20(18 ; 22)$ months in the $2^{\text {nd }}$ group.

The average duration of a telephone conversation was $7(5 ; 9)$ minutes. The most of patients and their relatives were positive and willing to communicate. In both groups, the interviewers spoke more often with patients' relatives than patients themselves.

An analysis of the interviewer's role and the assessment of the patient's condition were carried out. It was found that the results obtained by all specialists were the same and corresponded to the real patients' condition. The number of refuses to talk in all interviewers was also comparable. The data obtained were significant and did not depend on the researcher.

According to a telephone survey (Table 5), 89\% patients underwent the $2^{\text {nd }}$ stage rehabilitation in phase 1 , and $81 \%$ patients in phase $2(p=0.324)$. The 3rd stage rehabilitation was received by $50 \%$ phase 1 patients and $53 \%$ phase 2 patients $(p=0.7)$. In phase 2 , patients received rehabilitation in the institutions where the MDT specialists were trained. The $57 \%$ patients were directed to the 2 nd and 3 rd stages of rehabilitation immediately, avoiding getting home. This means that there was no break between the medical rehabilitation stages.

Since not all patients (only 237 people) were included in the sample, a comparison was made of the groups of patients who took part in a telephone interview according using the baseline indicators for the $1^{\text {st }}$ stage (Table 5). The disability prior to stroke baseline assessment obtained using mRS and the patient's history, was comparable in both groups $(p>0.05)$. The mRS disability score was also the same in the beginning of the $1^{\text {st }}$ stage $(p=0.967)$, which allowed us to compare the groups.

mRS assessment was the main endpoint of the study, it was performed by phone. The disability score in stroke patients after 1.5 years was in lower 2 nd group than in the $1^{\text {st }}$ group (Fisher exact test; $p<0.05$ ) (Fig. 2). The Mann-Whitney $U$ test showed that in the $1^{\text {st }}$ group the mRS score was $3(2 ; 4)$, and in the second group it was $2(1 ; 3)(p=0.026)$.

Mortality in both groups was comparable and did not differ significantly ( $1^{\text {st }}$ group, $15.5 \%$, 2nd group, $16 \%$ (Pearson $\chi^{2}$ test, $p=0.532$ ). Multidisciplinary rehabilitation together with specialized and high-tech medical care did not affect mortality within 1.5 years after a stroke.

The patients' quality of life in accordance to EuroQ-5D and VAS EuroQ-5D y the end of the study was comparable in both groups ( $p=0.1293$ and $p=0.0903$ ) (Table 5). However, a subanalysis showed that when using a patient-centered, problem-oriented multidisciplinary rehabilitation, the anxiety level in accordance with EuroQ-5D was lower (Mann-Whitney $U$ test; $p=0,0045$ ).

Rivermead Mobility Index score was better with a patientcentered, problem-oriented multidisciplinary rehabilitation

Table 4. Results of stroke patients condition evaluation at the end of the $1^{\text {st }}$ stage of rehabilitation

\begin{tabular}{|c|c|c|c|c|c|c|c|c|c|}
\hline & & \multirow{2}{*}{\multicolumn{2}{|c|}{ Scales }} & \multicolumn{3}{|c|}{$\begin{array}{c}\text { Significance, } \\
\text { pairwise comparison }\end{array}$} & \multicolumn{2}{|c|}{$\begin{array}{l}\text { Significance, } \\
\text { before and after rehabilitation } \\
\text { on the } 1^{\text {st }} \text { stage }\end{array}$} & \multirow[t]{2}{*}{ Tests } \\
\hline & & & & Phase 1 & Phase 2 & Tukey-Kramer test & Phase 1 & Phase 2 & \\
\hline \multicolumn{4}{|c|}{ NIHSS } & $5(3 ; 7)$ & $3(2 ; 7)$ & $>0.05$ & $<0.0001$ & $<0.0001$ & Tukey-Kramer test \\
\hline \multicolumn{4}{|l|}{ FIM } & $100(76 ; 114)$ & $118(103 ; 125)$ & $<0.0001$ & $<0.0001$ & $<0.0001$ & Tukey-Kramer test \\
\hline \multirow{2}{*}{\multicolumn{4}{|c|}{ Frenchay arm test }} & $5(3 ; 5)$ & $5(4.5 ; 5)$ & 1.0 & 0.0041 & & Wilcoxon test \\
\hline & & & & & & & 0.0604 & & $\chi^{2}$ \\
\hline \multicolumn{4}{|l|}{ BBS } & $42(27 ; 51)$ & $50.5(35 ; 54)$ & 0.0859 & $<0.0001$ & $<0.0001$ & Tukey-Kramer test \\
\hline \multirow{8}{*}{ MRC } & \multirow{4}{*}{ Hand } & Right & Proximal & $3(0 ; 5)$ & $4(0 ; 5)$ & \multicolumn{3}{|c|}{0.0355} & Mann-Whitney $U$ test \\
\hline & & \multirow{3}{*}{ Left } & Distal & $3(0 ; 5)$ & $4(0 ; 5)$ & \multicolumn{3}{|c|}{0.0062} & Mann-Whitney $U$ test \\
\hline & & & Proximal & $3(0 ; 5)$ & $3(0 ; 5)$ & \multicolumn{3}{|c|}{$<0.0001$} & Mann-Whitney $U$ test \\
\hline & & & Distal & $3(0 ; 5)$ & $4(0 ; 5)$ & \multicolumn{3}{|c|}{$<0.0001$} & Mann-Whitney $U$ test \\
\hline & \multirow{4}{*}{ Leg } & \multirow{2}{*}{ Right } & Proximal & $4(0 ; 5)$ & $4(0 ; 5)$ & \multicolumn{3}{|c|}{0.110} & Mann-Whitney $U$ test \\
\hline & & & Distal & $4(0 ; 5)$ & $4(0 ; 5)$ & \multicolumn{3}{|c|}{0.0236} & Mann-Whitney $U$ test \\
\hline & & \multirow{2}{*}{ Left } & Proximal & $4(0 ; 5)$ & $4(0 ; 5)$ & \multicolumn{3}{|c|}{0.0003} & Mann-Whitney $U$ test \\
\hline & & & Distal & $3(0 ; 4)$ & $3(0 ; 4)$ & \multicolumn{3}{|c|}{$<0.0001$} & Mann-Whitney $U$ test \\
\hline \multicolumn{4}{|c|}{ MASA } & $180(178 ; 180)$ & $180(178 ; 180)$ & 0.8284 & 0.0033 & 0.0594 & Tukey-Kramer test \\
\hline \multicolumn{4}{|c|}{ L. I. Wasserman psychodiagnostic scale } & $2(0 ; 10)$ & $0(0 ; 2)$ & 0.5578 & 0.0387 & 0.086 & Tukey-Kramer test \\
\hline \multicolumn{4}{|c|}{$\mathrm{MoCa}$} & $21.5(15 ; 25)$ & $23(19 ; 26)$ & $<0.0001$ & $p<0.0001$ & $p<0.0001$ & Tukey-Kramer test \\
\hline \multirow{2}{*}{\multicolumn{2}{|c|}{ HADS }} & & epression & $4(2 ; 7)$ & $7(3 ; 10)$ & 0.0318 & 0.0009 & 0.2435 & Tukey-Kramer test \\
\hline & & & Anxiety & $4(2 ; 7)$ & $5(3 ; 7)$ & 0.5422 & $<0.0001$ & 0.1048 & Tukey-Kramer test \\
\hline \multicolumn{4}{|c|}{ EuroQ-5D } & $8.5(6 ; 10)$ & $7(5 ; 10)$ & 0.0887 & 0.0896 & 0.567 & Tukey-Kramer test \\
\hline
\end{tabular}




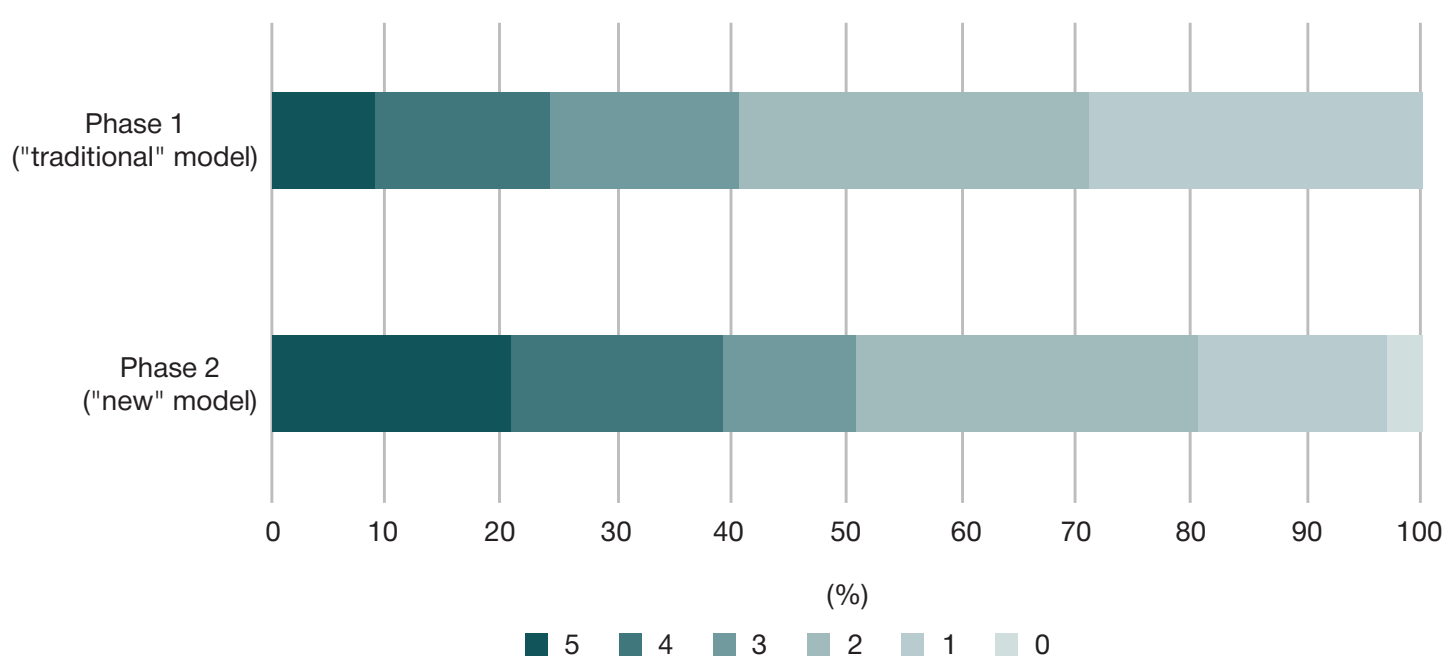

Fig. 2. mRS assessment carried out 1.5 years after stroke (score obtained during the telephone interview)

(14 (9; 14)) than with a biomedical model (13.5 (7; 14), $p=0.04)$, i.e. patients became more mobile 1.5 years after the stroke.

The proportion of patients who were constantly under the doctor's care (Table 5) was greater in phase 2, the differences were not significant $(p=0.123)$. In the phases 1 and 2 the same number of patients was controlled by neurologist, physician and other doctors $(p=0.123)$. Patient-centered problem-oriented multidisciplinary rehabilitation did not affect the patient's commitment to control his condition with doctor's assistance after completing 3-stage rehabilitation. Ten percent of patients who underwent rehabilitation according to the biomedical model refused to take drugs after the completion of treatment in medical institutions. When using a patient-centered problemoriented multidisciplinary rehabilitation, patients refused less often (4\% patients), however, there were no significant defferences $(p=0.23)$. Blood pressure was not controlled by $7 \%$ patients who underwent rehabilitation according to the biomedical model, and by $4 \%$ patients who underwent rehabilitation according to a multidisciplinary problem-oriented and patient-centered model $(p=0.73)$.

\section{DISCUSSION}

Introduction of a patient-centered problem-oriented multidisciplinary rehabilitation at the $1^{\text {st }}$ stage of treatment and rehabilitation in our study provided a significant decrease in the level of dependence in the daily life of stroke patients compared to the traditional rehabilitation model. The effect of the new rehabilitation model was associated with the rehabilitation optimization, better rehabilitation organization, focus on functional outcome, greater involvement of the patient and his relatives in the rehabilitation process, as well as greater patient's interest.

The patients' condition changes analysis (mRS) demonstrated that the proportion of patients who showed deterioration during the $1^{\text {st }}$ stage of medical rehabilitation in phase 2 was less than in phase 1. Deterioration was associated with pneumonia, urinary tract infections, pulmonary embolism, progression of cerebral edema, etc. Significant improvement (by 3 and 4) was possible only at the $1^{\text {st }}$ stage of rehabilitation, in patients who had functional disorders associated with "quick-fix" causes (stress, pain, brain edema, intoxication, acute infection, etc.). The use of a problem-oriented patient-centered and multidisciplinary rehabilitation model provides significant improvement, fewer patients show a deterioration during the rehabilitation.

The results obtained using the FIM scale emphasize the features of the rehabilitation intervention, which, in case of impossibility of function restoring, improves functioning due to the active patient's participation. FIM also reflects the efficiency of the occupational therapy and physical therapy specialists.

Assessment using the Frenchay test demonstrated that the scale was not so sensitive and did not fully reflect the effects of rehabilitation. It may be necessary to use more sensitive evaluation instruments (for example, the ARAT test).

The Berg Balance Scale showed the effectiveness of the physical therapists' work in phase 2. Assessment using MASA and L. I. Wasserman scale for estimating the degree of speech disorders in patients with local brain injuries demonstrated the ceiling effect. Good speech and swallowing recovery were associated with the effective work of speech-language pathologists in both phase 1 and phase 2 .

In patients with stroke, cognitive impairment could be both a manifestation of a stroke and premorbid disorders associated with cerebrovascular risk factors. In some cases, a combination of one and the other could be present. The best recovery of cognitive functions (MoCa) in phase 2 demonstrated the advantage of the patient-centered problem-oriented approach in the work of MDT psychologists.

Assessment using the HADS scale used for screening assessment of emotional disturbances in patients with cerebral stroke revealed a higher level of subclinical depression in the phase 2 patients. That could be due to a higher level of patient's awareness and difficulty in adaptation during phase 2, which, among other things, was evidenced by a better restoration of cognitive functions in phase 2 . It is likely that the use of a wider range of diagnostic tools will allow us to study the manifestations of emotional disturbances in patients with cerebral stroke during the recovery period better.

Evaluation using EuroQ-5D showed a comparable level of quality of life in both groups. The lack of improvement in the quality of life at the $1^{\text {st }}$ stage could be due to the necessity of a hospital stay, communication with strangers and other factors. A delayed assessment may provide an opportunity to obtain objective information about the patients' quality of life.

Hospitalization period duration change and, as a result, the economic efficiency of rehabilitation indicates the impossibility of introducing the fixed periods of hospitalization for rehabilitation patients, since the needs of patients with stroke, and therefore the duration of rehabilitation, can be different. It is necessary to link the duration of hospitalization with the rehabilitation potential implementation and the rehabilitation goals achievement set upon admission of the patient to each stage. 
Table 5. Groups of patients' baseline indicators and results obtained during the telephone interview

\begin{tabular}{|c|c|c|c|c|c|}
\hline Scales and questionnaires & \multicolumn{2}{|l|}{ Phase 1} & Phase 2 & Significance & Test \\
\hline $\begin{array}{l}\text { Time between entering the } 1^{\text {st }} \text { stage and } \\
\text { the telephone interview, months }\end{array}$ & \multicolumn{2}{|l|}{$21(19 ; 23)$} & $20(18 ; 22)$ & 0.09 & Mann-Whitney $U$ test \\
\hline mRS score before stroke 0 & \multicolumn{2}{|l|}{$80 \%$} & $79 \%$ & \multirow{2}{*}{0.47} & \multirow{4}{*}{ Fisher's exact test } \\
\hline mRS score before stroke 1 & \multicolumn{2}{|l|}{$20 \%$} & $21 \%$ & & \\
\hline Relatives answered the call & \multicolumn{2}{|l|}{$73 \%$} & $66 \%$ & \multirow{2}{*}{0.194} & \\
\hline Patient answered the call himself & \multicolumn{2}{|l|}{$27 \%$} & $34 \%$ & & \\
\hline $\mathrm{mRS}$ score when entering the $1^{\text {st }}$ stage & \multicolumn{2}{|l|}{$3(3 ; 4)$} & $3(3 ; 4)$ & 0.967 & Mann-Whitney $U$ test \\
\hline mRS score 0 & \multirow{6}{*}{$\begin{array}{l}\text { When entering } \\
\text { the } 1^{\text {st }} \text { stage }\end{array}$} & $0 \%$ & $0 \%$ & \multirow{6}{*}{0.109} & \multirow{6}{*}{ Fisher's exact test } \\
\hline mRS score 1 & & $0 \%$ & $0 \%$ & & \\
\hline mRS score 2 & & $14 \%$ & $12 \%$ & & \\
\hline mRS score 3 & & $29 \%$ & $30 \%$ & & \\
\hline mRS score 4 & & $43 \%$ & $45 \%$ & & \\
\hline mRS score 5 & & $14 \%$ & $13 \%$ & & \\
\hline Rivermead Mobility Index & \multicolumn{2}{|l|}{$13.5(7 ; 14)$} & $14(9 ; 14)$ & 0.04 & \multirow{17}{*}{ Mann-Whitney $U$ test } \\
\hline Total EuroQ-5D & \multicolumn{2}{|l|}{$7(5 ; 10)$} & $6(5 ; 8)$ & 0.1293 & \\
\hline VAS EuroQ-5D, \% & \multicolumn{2}{|l|}{$50(20 ; 70)$} & $50(50 ; 70)$ & 0.0903 & \\
\hline EuroQ-5D Mobility & \multicolumn{2}{|l|}{$2(1 ; 2)$} & $2(1 ; 2)$ & 0.5097 & \\
\hline EuroQ-5D Self-care & \multicolumn{2}{|l|}{$1(1 ; 2)$} & $1(1 ; 2)$ & 0.1517 & \\
\hline EuroQ-5D Usual activities & \multicolumn{2}{|l|}{$2(1 ; 2)$} & $1(1 ; 2)$ & 0.2346 & \\
\hline EuroQ-5D Pain/discomfort & \multicolumn{2}{|l|}{$2(1 ; 2)$} & $1(1 ; 2)$ & 0.125 & \\
\hline EuroQ-5D Anxiety/depression & \multicolumn{2}{|l|}{$2(1 ; 2)$} & $1(1 ; 2)$ & 0.0045 & \\
\hline Underwent rehabilitation at the $2^{\text {nd }}$ stage & \multicolumn{2}{|l|}{$89.25 \%$} & $81.33 \%$ & 0.342 & \\
\hline Underwent rehabilitation at the $3^{\text {rd }}$ stage & \multicolumn{2}{|l|}{$50.00 \%$} & $52.78 \%$ & 0.7 & \\
\hline Obesity & \multicolumn{2}{|l|}{$37.78 \%$} & $34.78 \%$ & 0.251 & \\
\hline Was under no doctor's care & \multicolumn{2}{|l|}{$33.33 \%$} & $27.14 \%$ & \multirow{4}{*}{0.123} & \\
\hline Was under neurologist's care & \multicolumn{2}{|l|}{$22.22 \%$} & $20.00 \%$ & & \\
\hline Was under physician's care & \multicolumn{2}{|l|}{$30.00 \%$} & $22.86 \%$ & & \\
\hline Was under other doctor's care & \multicolumn{2}{|l|}{$14.44 \%$} & $30.00 \%$ & & \\
\hline Did not receive any medicine & \multicolumn{2}{|l|}{$10.11 \%$} & $4.29 \%$ & 0.23 & \\
\hline Did not control blood pressure & $6.74 \%$ & & $4.29 \%$ & 73 & \\
\hline
\end{tabular}

An equal number of patients who received rehabilitation in the $2^{\text {nd }}$ and $3^{\text {rd }}$ stages contributed to the objectivity of the study, since the amount of care received by patients of phases 1 and 2 is the same. However, the quality of care received by patients in the $2^{\text {nd }}$ and $3^{\text {rd }}$ stages of the study in the institutions where the teams implemented the multidisciplinary patient-centered problem-oriented model was significantly higher.

Analysis of the main study endpoints demonstrated that patient-centered, problem-oriented multidisciplinary medical rehabilitation was more effective than traditional rehabilitation of patients with stroke. It was shown that the rehabilitation effect maintained at least for 1.5 years, which indicated its persistence. Most of phase 1 patients did not pass to the $2^{\text {nd }}$ and $3^{\text {rd }}$ stage of rehabilitation immediately and "dropped out" of observation. After the $1^{\text {st }}$ stage discharge patients registered in the waiting list and received rehabilitation after months and years when the rehabilitation efficiency became lower. In phase 2, the number of patients who received rehabilitation at the second and third stages in the participating institutions was significantly larger. However, given the small sample size in phase 1 of the study, no statistical analysis was performed. In phase 2 , a continuity ensuring system was created, which, with an equal amount of assistance provided, demonstrated higher quality and better effect of rehabilitation treatment.

The convenience of data collecting trough telephone interviews using a number of scales is noteworthy. Telephone interviews allow one to evaluate the patient's mobility using the Rivermead Mobility Index, to obtain information on complications and recurrent events, as well as mortality and disability severity $(\mathrm{mRS})$. During the telephone interviews, we managed to obtain valuable information about the patients' condition and the persistence of the rehabilitation, which could be used to create databases on the volume and quality of medical care provided.

\section{CONCLUSION}

Three-stage patient-centered, problem-oriented, multidisciplinary model is more cost-efficient, since the model ensures better recovery of patients after stroke, improves the quality of life and patient adherence to treatment, reduces secondary healthcare costs, and helps to reduce the cost of specialized and hightech medical care for said category of patients. 
1. Sycheva AV. Multidisciplinary approach in the recovery treatment of the consequences of cerebral stroke [dissertation]. M., 2008. Russian.

2. Stroke Unit Trialists' Collaboration. Organised inpatient (stroke unit) care for stroke. Cochrane Database Syst Rev. 2013 Sep 11; 9: CD000197.

3. Turner-Stokes L, Pick A, Nair A, Disler PB, Wade DT. Multidisciplinary rehabilitation for acquired brain injury in adults of working age. Cochrane Database Syst Rev. 2015 Dec 22; 12 : CD004170,

4. European Physical and Rehabilitation Medicine Bodies Alliance. White Book on Physical and Rehabilitation Medicine (PRM) in Europe. Chapter 8. The PRM specialty in the healthcare system and society. Eur J Phys Rehabil Med. 2018; 54 (2): 261-78.

5. European Physical and Rehabilitation Medicine Bodies Alliance. White Book on Physical and Rehabilitation Medicine (PRM) in Europe. Chapter 7. The clinical field of competence: PRM in practice. Eur J Phys Rehabil Med. 2018; 54 (2): 230-60.

6. European Physical and Rehabilitation Medicine Bodies Alliance. White Book on Physical and Rehabilitation Medicine (PRM) in Europe. Chapter 6. Knowledge and skills of PRM physicians. Eur J Phys Rehabil Med. 2018; 54 (2): 214-29.

7. Ivanova GE, Aronov DM, Belkin AA, Belyaev AF, Bodrova RA, Bubnova MG, et al. Pilot Project "Development of Medical Rehabilitation System in the Russian Federation». Journal of Restorative Medicine. 2016; (2): 2-6.

8. Ivanova GE, Belkin AA, Belyaev AF, Bodrova RA, Bujlova TV, Melnikova EV, et al. Pilot project "Development of medical rehabilitation system in the Russian Federation." General Principles and Protocol. Journal of the Ivanovsky Medical Academy. 2016; 21 (1): 6-11.

9. Ivanova GE, Belkin AA, Belyaev AF, Bodrova RA, Melnikova EV, Prokopenko SV, et al. Pilot project "Development of medical rehabilitation system in the Russian Federation." System of monitoring and monitoring the effectiveness of medical rehabilitation in case of acute disorders of cerebral circulation. Journal of the Ivanovsky Medical Academy. 2016; 21 (1): 19-22.

10. On the procedure for organizing medical rehabilitation. Pub. L. of the Ministry of Healthcare of the Russian Federation № 1705n (Dec. 29, 2012).

11. On approval of the procedure for medical care for patients with Stroke. Pub. L. of the Ministry of Healthcare of the Russian Federation № 928n (Nov. 15, 2012).

12. Zabolotskih IB, Shifman EM, redaktory. Klinicheskie rekomendacii. Anesteziologija-reanimatologija. M.: GJeOTAR-Media, 2016; p. 873928. Russian.

13. European Physical and Rehabilitation Medicine Bodies Alliance.
White Book on Physical and Rehabilitation Medicine (PRM) in Europe. Chapter 11. Challenges and perspectives for the future of PRM. Eur J Phys Rehabil Med. 2018; 54 (2): 311-21.

14. European Physical and Rehabilitation Medicine Bodies Alliance. White Book on Physical and Rehabilitation Medicine (PRM) in Europe. Chapter 10, Science and research in PRM: specificities and challenges. Eur J Phys Rehabil Med. 2018; 54 (2): 287-310.

15. European Physical and Rehabilitation Medicine Bodies Alliance. White Book on Physical and Rehabilitation Medicine (PRM) in Europe. Chapter 9. Education and continuous professional development: shaping the future of PRM. Eur J Phys Rehabil Med. 2018; 54 (2): 279-86.

16. European Physical and Rehabilitation Medicine Bodies Alliance. White Book on Physical and Rehabilitation Medicine (PRM) in Europe. Chapter 5. The PRM organizations in Europe: structure and activities. Eur J Phys Rehabil Med. 2018; 54 (2): 198-213.

17. European Physical and Rehabilitation Medicine Bodies Alliance. White Book on Physical and Rehabilitation Medicine (PRM) in Europe. Chapter 4. History of the specialty: where PRM comes from. Eur J Phys Rehabil Med. 2018; 54 (2): 186-97.

18. European Physical and Rehabilitation Medicine Bodies Alliance. White Book on Physical and Rehabilitation Medicine (PRM) in Europe. Chapter 3. A primary medical specialty: the fundamentals of PRM. Eur J Phys Rehabil Med. 2018; 54 (2): 177-85.

19. European Physical and Rehabilitation Medicine Bodies Alliance. White Book on Physical and Rehabilitation Medicine in Europe. Chapter 2 . Why rehabilitation is needed by individual and society. Eur J Phys Rehabil Med. 2018; 54 (2): 166-76.

20. European Physical and Rehabilitation Medicine Bodies Alliance. White Book on Physical and Rehabilitation Medicine (PRM) in Europe. Chapter 1. Definitions and concepts of PRM. Eur J Phys Rehabil Med. 2018; 54 (2): 156-65.

21. European Physical and Rehabilitation Medicine Bodies Alliance. White Book on Physical and Rehabilitation Medicine in Europe. Introductions, Executive Summary, and Methodology. Eur J Phys Rehabil Med. 2018; 54 (2): 125-55.

22. Ivanova GE, Melnikova EV, Shmonin AA, Aronov DM, Belkin AA, Belyaev AF, et al. Pilot project "Development of medica rehabilitation system in the Russian Federation". Protocol of the second phase of the project. Scientific notes of PSPbGMU. 2016; (2): 27-34.

23. Ivanova GE, Melnikova EV, Shmonin AA, Verbitskaya EV, Aronov DM, Belkin AA, et al. Pilot Project "Development of Medical Rehabilitation System in the Russian Federation": Preliminary Results at the First and Second Stages. Journal of Restorative Medicine. 2017; 2 (78): 10-15.

\section{Литература}

1. Сычева A. В. Мультидисциплинарный подход при восстановительном лечении последствий церебрального инсульта [диссертация]. М., 2008.

2. Stroke Unit Trialists' Collaboration. Organised inpatient (stroke unit) care for stroke. Cochrane Database Syst Rev. 2013 Sep 11; 9: CD000197.

3. Turner-Stokes L, Pick A, Nair A, Disler PB, Wade DT. Multidisciplinary rehabilitation for acquired brain injury in adults of working age. Cochrane Database Syst Rev. 2015 Dec 22; 12: CD004170

4. European Physical and Rehabilitation Medicine Bodies Alliance. White Book on Physical and Rehabilitation Medicine (PRM) in Europe. Chapter 8. The PRM specialty in the healthcare system and society. Eur J Phys Rehabil Med. 2018; 54 (2): 261-78.

5. European Physical and Rehabilitation Medicine Bodies Alliance. White Book on Physical and Rehabilitation Medicine (PRM) in Europe. Chapter 7. The clinical field of competence: PRM in practice. Eur J Phys Rehabil Med. 2018; 54 (2): 230-60.

6. European Physical and Rehabilitation Medicine Bodies Alliance. White Book on Physical and Rehabilitation Medicine (PRM) in

Europe. Chapter 6. Knowledge and skills of PRM physicians. Eur J Phys Rehabil Med. 2018; 54 (2): 214-29.

7. Иванова Г. Е., Аронов Д. М., Белкин А. А., Беляев А. Ф. Бодрова Р. А., Бубнова М. Г. и др. Пилотный проект «Развитие системы медицинской реабилитации в РФ». Вестник восстановительной медицины. 2016; (2): 2-6.

8. Иванова Г. Е., Белкин А. А., Беляев А. Ф., Бодрова Р. А., Буйлова Т. В., Мельникова Е. В. и др. Пилотный проект «Развитие системы медицинской реабилитации в Российской Федерации». Общие принципы и протокол. Вестник Ивановской медицинской академии. 2016; 21 (1): 6-11.

9. Иванова Г. Е., Белкин А. А., Беляев А. Ф., Бодрова Р. А., Мельникова Е. В., Прокопенко С. В. и др. Пилотный проект «Развитие системы медицинской реабилитации в Российской Федерации». Система контроля и мониторирования эффективности медицинской реабилитации при острых нарушениях мозгового кровообращения. Вестник Ивановской медицинской академии. 2016; 21 (1): 19-22.

10. Приказ Министерства здравоохранения Российской Федерации № 1705н от 29.12.2012. «О порядке организации 
медицинской реабилитации".

11. Приказ Министерства здравоохранения Российской Федерации № 928н от 15.11.2012. «Об утверждении порядка медицинской помощи больным с нарушениями мозгового кровообращения".

12. Заболотских И. Б., Шифрман Е. М., редакторы. Клинические рекомендации. Анестезиология-реаниматология. М.: ГЭОТАРМедиа, 2016; с. 873-928.

13. European Physical and Rehabilitation Medicine Bodies Alliance. White Book on Physical and Rehabilitation Medicine (PRM) in Europe. Chapter 11. Challenges and perspectives for the future of PRM. Eur J Phys Rehabil Med. 2018; 54 (2): 311-21.

14. European Physical and Rehabilitation Medicine Bodies Alliance. White Book on Physical and Rehabilitation Medicine (PRM) in Europe. Chapter 10, Science and research in PRM: specificities and challenges. Eur J Phys Rehabil Med. 2018; 54 (2): 287-310.

15. European Physical and Rehabilitation Medicine Bodies Alliance. White Book on Physical and Rehabilitation Medicine (PRM) in Europe. Chapter 9. Education and continuous professional development: shaping the future of PRM. Eur J Phys Rehabil Med. 2018; 54 (2): 279-86.

16. European Physical and Rehabilitation Medicine Bodies Alliance. White Book on Physical and Rehabilitation Medicine (PRM) in Europe. Chapter 5. The PRM organizations in Europe: structure and activities. Eur J Phys Rehabil Med. 2018; 54 (2): 198-213.

17. European Physical and Rehabilitation Medicine Bodies Alliance. White Book on Physical and Rehabilitation Medicine (PRM) in
Europe. Chapter 4. History of the specialty: where PRM comes from. Eur J Phys Rehabil Med. 2018; 54 (2): 186-97.

18. European Physical and Rehabilitation Medicine Bodies Alliance. White Book on Physical and Rehabilitation Medicine (PRM) in Europe. Chapter 3. A primary medical specialty: the fundamentals of PRM. Eur J Phys Rehabil Med. 2018; 54 (2): 177-85.

19. European Physical and Rehabilitation Medicine Bodies Alliance. White Book on Physical and Rehabilitation Medicine in Europe. Chapter 2. Why rehabilitation is needed by individual and society. Eur J Phys Rehabil Med. 2018; 54 (2): 166-76.

20. European Physical and Rehabilitation Medicine Bodies Alliance. White Book on Physical and Rehabilitation Medicine (PRM) in Europe. Chapter 1. Definitions and concepts of PRM. Eur J Phys Rehabil Med. 2018; 54 (2): 156-65.

21. European Physical and Rehabilitation Medicine Bodies Alliance. White Book on Physical and Rehabilitation Medicine in Europe. Introductions, Executive Summary, and Methodology. Eur J Phys Rehabil Med. 2018; 54 (2): 125-55.

22. Иванова Г. Е., Мельникова Е. В., Шмонин А. А., Аронов Д. М., Белкин А. А., Беляев А. Ф. и др. Пилотный проект «Развитие системы медицинской реабилитации В Российской Федерации». Протокол второй фазы проекта. Ученые записки ПСПбГМУ им. акад. И. П. Павлова. 2016; (2): 27-34.

23. Иванова Г. Е., Мельникова Е. В., Шмонин А. А., Вербицкая Е. В., Аронов Д. М., Белкин А. А. и др. Пилотный проект «Развитие системы медицинской реабилитации в Российской Федерации:: предварительные результаты на первом и втором этапах. Вестник восстановительной медицины. 2017; 2 (78): 10-15. 